Article

\title{
Coulsonite $\mathrm{FeV}_{2} \mathrm{O}_{4}$-A Rare Vanadium Spinel Group Mineral in Metamorphosed Massive Sulfide Ores of the Kola Region, Russia
}

\author{
Alena A. Kompanchenko \\ Geological Institute of the Federal Research Centre "Kola Science Centre of the Russian Academy of Sciences", \\ 14 Fersman Street, 184209 Apatity, Russia; komp-alena@yandex.ru; Tel.: +7-921-048-8782 \\ Received: 24 August 2020; Accepted: 21 September 2020; Published: 24 September 2020

\begin{abstract}
This work presents new data on a rare vanadium spinel group mineral, i.e., coulsonite $\mathrm{FeV}_{2} \mathrm{O}_{4}$ established in massive sulfide ores of the Bragino occurrence in the Kola region, Russia. Coulsonite in massive sulfide ores of the Bragino occurrence is one of the most common vanadium minerals. Three varieties of coulsonite were established based on its chemical composition, some physical properties, and mineral association: coulsonite-I, coulsonite-II, and coulsonite-III. Coulsonite-I forms octahedral crystal clusters of up to $500 \mu \mathrm{m}$, and has a uniformly high content of $\mathrm{Cr}_{2} \mathrm{O}_{3}$ (20-30 wt.\%), $\mathrm{ZnO}$ (up to $4.5 \mathrm{wt} . \%$ ), and $\mathrm{MnO}$ (2.8 wt. \%), high microhardness ( $743 \mathrm{~kg} / \mathrm{mm}^{2}$ ) and coefficient of reflection. Coulsonite-II was found in relics of quartz-albite veins in association with other vanadium minerals. Its features are a thin tabular shape and enrichment in $\mathrm{TiO}_{2}$ of up to $18 \mathrm{wt} . \%$. Coulsonite-III is the most common variety in massive sulfide ores of the Bragino occurrence. Coulsonite-III forms octahedral crystals of up to $150 \mu \mathrm{m}$, crystal clusters, and intergrowths with V-bearing ilmenite, W-V-bearing rutile, Sc-V-bearing senaite, etc. Chemical composition of coulsonite-III is characterized by wide variation of the major compounds- $\mathrm{Fe}, \mathrm{V}, \mathrm{Cr}$. In some crystals of coulsonite-III, relics of chromite are observed. The microhardness of coulsonite-III is $577 \mathrm{~kg} / \mathrm{mm}^{2}$, the reflection coefficient changes in relation to iron, vanadium, and chromium content.
\end{abstract}

Keywords: spinel group mineral; coulsonite; vanadium; massive sulfide ore; metamorphism; Paleoproterozoic; Kola region

\section{Introduction}

Coulsonite is a naturally occurring iron-vanadium spinel group mineral with formula $\mathrm{FeV}_{2} \mathrm{O}_{4}$. According to www.midat.org, the type locality of coulsonite is the Buena Vista Hills east of Lovelock, Nevada (USA) where coulsonite was identified in magnetite-bearing rocks. The mineral occurs as an ilmenite-like exsolution in magnetite and disseminated subhedral crystals in silicate gangue separated from magnetite [1].

Many findings of rare vanadium minerals, including vanadium spinel, are connected with high-grade metamorphic complexes where two main conditions are required: primary enrichment of host rock in vanadium and high degree of metamorphism (up to amphibolite facies). For example, the only tanzanite deposit in the world is in Tanzania [2,3]. A lot of vanadium minerals were found in metamorphic rock of the Sludyanka complex in the southern Baikal area (Russia), such as new mineral species, including magnesiocoulsonite $\mathrm{MgV}_{2} \mathrm{O}_{4}$ [4-7]. Yet, the most significant findings of vanadium spinel group minerals are associated with metamorphosed massive sulfide ores described only in supracrustal units of several Paleoproterozoic rift-related structures of ancient cratons worldwide.

Coulsonite, along with other vanadium minerals, was identified in massive sulfide ores in the Kola region (Russia), the Vihanti (Finland) and the Rampura Agucha (India) deposits [8-11]. The third 
vanadium spinel, vourelainenite $\mathrm{MnV}_{2} \mathrm{O}_{4}$, was discovered in massive sulfide ores in the Sätra deposit (Sweden) [12] and also found in the Outokumpu deposit (Finland) [13]. All these massive sulfide ore deposits and occurrences have similar main characteristics: geological position (Paleoproterozoic rift-related structure), time of formation (ca. $1.9 \mathrm{Ga}$ ), high degree of metamorphism (up to amphibolite or even granulite facies), and mineral composition (the main mineral is pyrrhotite) [14-21].

Vanadium mineralization in the Kola region was earlier partially described [22]. This work provides data on a more detailed study of coulsonite, i.e., the main vanadium mineral in the Kola region massive sulfide ores. Data on coulsonite from the Bragino and Pyrrhotite Ravine occurrences after [8] were obtained by the author of this work.

\section{Geological Setting}

A detailed description of the geological setting was given in [23], therefore in this work only brief overview is presented.

Occurrences and deposits of massive sulfide ores of the Kola region are located in the Pechenga-Imandra-Varzuga Paleoproterozoic riftogenic belt, which formed during 2.5-1.7 Ga [24-27].

The Bragino massive sulfide ore occurrence is located in basic volcanics of the Mennel formation, which belongs to the central part of the South Pechenga structural zone (Figure 1). These rocks are depleted in $\mathrm{K}, \mathrm{Sr}, \mathrm{Rb}, \mathrm{Ta}, \mathrm{Zr}, \mathrm{Hf}$, Ti, light and heavy rare-earth elements, and enriched in $\mathrm{Ba}$, Th, and $\mathrm{Nb}$. Host rock for the Bragino occurrence belong to low-alkali and Fe-Mg-enriched rocks of the normal-type mid-ocean ridge basalts (MORB) $[28,29]$. The vanadium content in volcanics of the Mennel formation varies between 160 and 450 ppm [28], which is just slightly higher than that in the Earth's crust (138 ppm) [30]. There is an imprecise Sm-Nd age of $1.89 \pm 0.04$ [29], as well as $\mathrm{Rb}-\mathrm{Sr}$ isochron whole-rock ages of $1.87 \pm 0.05$ [31]. The Bragino occurrence host rock was metamorphosed in amphibolite facies [28,29].

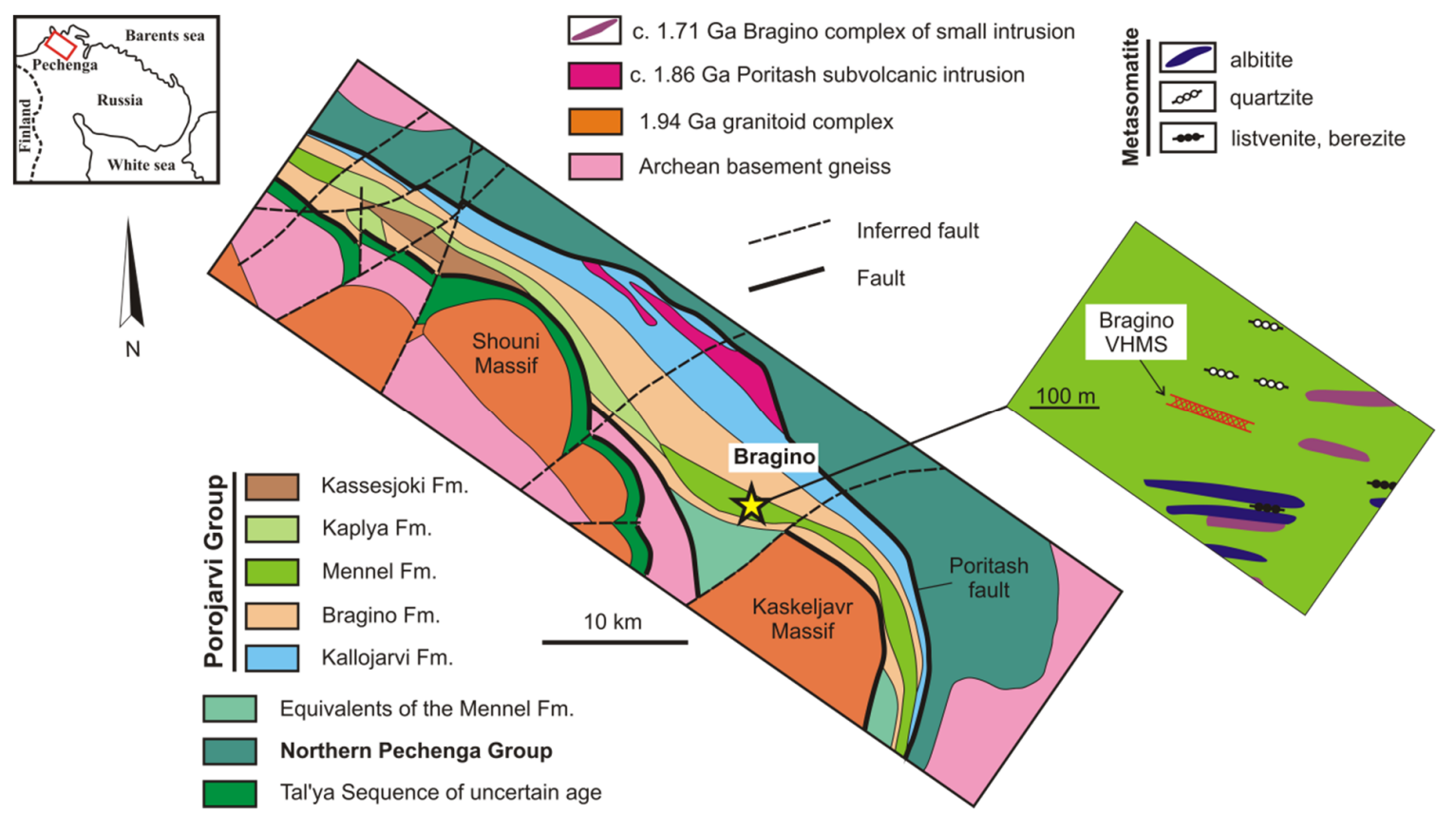

Figure 1. Geological map of the South Pechenga structural zone and position of the Bragino occurrence (modified after [22,24,26,28,32]).

According to a previous study [32] and the author's field observations, an ore body of the Bragino occurrence is a lens up to $7 \mathrm{~m}$ in thickness, ca. $100 \mathrm{~m}$ in length, and $70-75^{\circ}$ dip. The most part of the ore body is covered with quaternary sediments. Thirty samples of massive sulfide ores with an average weight of $2 \mathrm{~kg}$ were cut from bedrock outcrops. 
Based on the texture of the ores, four of ores types were distinguished within the Bragino occurrence: massive, banded, brecciated, and disseminated. Massive ores are the most common. This ore type can be divided into three subtypes based on their mineralogical composition: massive pyrrhotite ores of type I (mPo-I), massive pyrrhotite ores of the type II (mPo-II), and massive pyrite ores [23]. These ore types will be considered below. The content of $\mathrm{V}_{2} \mathrm{O}_{5}$ in these ores does not exceed $0.06 \%$.

\section{Methods}

The microscopic study of ore minerals in reflected light was conducted using an optical microscope Axioplane. Chemical analyses of the minerals were carried out by the Cameca MS-46 electron probe microanalyzer (Geological Institute, Kola Science Centre of the RAS, Apatity, Russia), WDS (Wavelength Dispersive Spectrometer) mode, 22 kV, 20-30 nA, 5-20 $\mu \mathrm{m}$ beam diameter (Cameca, Gennevilliers, France). The following standards (and analytical lines) were used: diopside ( $\mathrm{Si} K \alpha, \mathrm{Ca} K \alpha)$, anatase (TiK $\alpha$ ), $\mathrm{MnCO}_{3}(\mathrm{MnK} \alpha)$, pyrope $(\mathrm{Al} K \alpha, \mathrm{MgK} \alpha)$, magnetite $(\mathrm{Fe} K \alpha)$, chromite $(\mathrm{Cr} K \alpha)$, and metallic vanadium $(\mathrm{VK} \alpha)$. Detection limits of electron microprobe analyses (wt.\%): Al-0.05, Si-0.05, Mn-0.01, Fe-0.01, $\mathrm{Zn}-0.01, \mathrm{Ti}-0.02, \mathrm{Cr}-0.02, \mathrm{~V}-0.02$. Element distribution, morphology, and intraphase heterogeneity were also determined using a LEO-1450 scanning electron microscope (SEM) (Carl Zeiss, Oberkochen, Germany) equipped with a Bruker XFlash-5010 Nano GmbH (Bruker, Bremen, Germany) energy dispersive spectrometer (EDS) and an SEM Hitachi S-3400N (Hitachi, Tokyo, Japan) equipped with a EDS Oxford X-Max 20 (Oxford Instruments, Abington, UK). An EBSD diffraction picture was obtained on an SEM Hitachi S-3400N (Hitachi, Tokyo, Japan) equipped with an EBSD-detector Oxford HKL Nordlys Nano (Oxford Instruments, Abington, UK): accelerating voltage $20 \mathrm{kV}$, beam current $1 \mathrm{nA}$, acquisition time $16 \mathrm{~s}$. Oxford Instruments AZtecHKL analysis software was used to identify minerals. Preparation of the sample surface for EBSD was made on an Oxford IonFab 300 by argon plasma for $10 \mathrm{~min}$. Registration of reflection spectrum was conducted on an MSF-21 microspectrofotometer (USSR), monochromator slit $0.4 \mathrm{~mm}$, zond $0.1 \mathrm{~mm}$, registration of spectrum is automatic per $20 \mathrm{~nm}$, range 400-700 nm, standard SiC (Reflexionsstandard -474251, № 545, Germany). Microhardness measures were taken using a PMT-3 device on a 50-g load.

\section{Results}

Coulsonite in massive sulfide ores of the Bragino occurrence is one of the most common vanadium minerals. Three varieties of coulsonite were defined based on the chemical composition, some physical properties and mineral association: coulsonite-I, coulsonite-II, and coulsonite-III. These varieties are briefly described in (Table 1). 
Table 1. Comparison of coulsonite varieties in massive sulfide ore of the Kola region.

\begin{tabular}{|c|c|c|c|c|c|c|}
\hline $\begin{array}{l}\text { Characteristics/Varieties } \\
\text { of Coulsonite }\end{array}$ & Ore Type & Morphology & Mineral Paragenesis & $\begin{array}{l}\text { Special Features of } \\
\text { Chemical Composition }\end{array}$ & Physical Properties & $\begin{array}{l}\text { Alleged } \\
\text { Genesis }\end{array}$ \\
\hline Coulsonite [8] & Banded pyrrhotite ore & $\begin{array}{l}\text { Corroded crystals and } \\
\text { growth up to } 100 \mu \mathrm{m}\end{array}$ & $\begin{array}{c}\text { Rim of mukhinite } \\
\text { or/and goldmanite, } \\
\text { V-bearing epidote and } \\
\text { grossular }\end{array}$ & $\begin{array}{l}\text { High Mn content, low Fe } \\
\text { and Cr content }\end{array}$ & $\begin{array}{l}\text { Microhardness close } \\
\text { to reference, } \\
\text { coefficient of } \\
\text { reflection accepted by } \\
\text { author of this work as } \\
\text { a standart }\end{array}$ & Metamorphic \\
\hline coulsonite-III & $\begin{array}{l}\text { Massive pyrrhotite } \\
\text { ore of type II and } \\
\text { massive pyrite ore }\end{array}$ & $\begin{array}{l}\text { Various, crystals and } \\
\text { growth up to } \\
100-150 \mu \mathrm{m}\end{array}$ & $\begin{array}{l}\text { 1. W-V-bearing rutile, } \\
\text { ilmenite } \\
\text { 2. V-bearing ilmenite, } \\
\text { ferberite } \\
\text { 3. Rim of magnetite } \\
\text { 4. Nolanite }\end{array}$ & $\begin{array}{l}\text { Minimal Mn content, } \\
\text { high variation of } \mathrm{Cr} \text {, Fe } \\
\text { and } \mathrm{V} \text { content }\end{array}$ & $\begin{array}{l}\text { Increased } \\
\text { microhardness } 577 \\
\mathrm{~kg} / \mathrm{mm}^{2} \text {, coefficient of } \\
\text { reflection lower than } \\
\text { that to coulsonite }\end{array}$ & Metamorphic \\
\hline coulsonite-II & $\begin{array}{l}\text { Relics of quartz-albite } \\
\text { veins in the massive } \\
\text { pyrrhotite ore of type } \\
\text { II and massive pyrite }\end{array}$ & $\begin{array}{l}\text { Lamellar (needle-like } \\
\text { in slice) crystals and } \\
\text { growth up to } \\
10 \times 30 \mu \mathrm{m}\end{array}$ & $\begin{array}{l}\text { V-bearing muscovite, } \\
\text { roscoelite, crictonite } \\
\text { group minerals, rutile, } \\
\text { byrudite, tivanite, } \\
\text { thortveitite, siderite }\end{array}$ & $\begin{array}{l}\text { Increased Fe content, and } \\
\text { Ti in some crystals }\end{array}$ & $\begin{array}{l}\text { High-titanium } \\
\text { crystals have the } \\
\text { highest coefficient of } \\
\text { reflection }\end{array}$ & Hydrothermal \\
\hline coulsonite-I & $\begin{array}{l}\text { Massive pyrrhotite } \\
\text { ore type } 1\end{array}$ & $\begin{array}{l}\text { Octahedral crystals } \\
\text { and growth up to } \\
300-500 \mu \mathrm{m}\end{array}$ & $\begin{array}{l}\text { W-V-bearing rutile, } \\
\text { V-bearing senaite, } \\
\text { V-bearing phlogopite }\end{array}$ & $\begin{array}{l}\text { Increased } \mathrm{Zn} \text { and } \mathrm{Mn} \\
\text { content, almost complete } \\
\text { absence of } \mathrm{Fe}^{3+}, \\
\text { uniformly high } \mathrm{Cr} \\
\text { content }\end{array}$ & $\begin{array}{l}\text { High microhardness } \\
743 \mathrm{~kg} / \mathrm{mm}^{2}, \text { low } \\
\text { chromite-like } \\
\text { coefficient of } \\
\text { reflection }\end{array}$ & Metamorphic \\
\hline
\end{tabular}




\subsection{Coulsonite-I}

Coulsonite-I was found in massive pyrrhotite ores of type I. It consists of a hexagonal and monocline pyrrhotite mixture ( $80 \%$ of ores) ( 1 in Figure $2 \mathrm{a}-\mathrm{c}$ ) and microveins of hexagonal pyrrhotite ( 2 in Figure $2 a, b)$. In the oxidation zone, pyrrhotite is replaced by a pyrite-marcasite intergrowth with "bird's eye" structure (up to $18 \%$ of this ore) (3 in Figure $2 \mathrm{a}-\mathrm{c}$ ). The mineral composition of this ore type is rather poor, $2 \%$ is accessory minerals: chalcopyrite, galena, molybdenite, coulsonite, V-bearing phlogopite and clinochlore intergrowth, Sc-V-bearing senaite, and W-V-bearing rutile [23].

Coulsonite-I occurs as octahedral crystals and crystal clusters up to $500 \mu \mathrm{m}$ (Figure $2 \mathrm{~d}-\mathrm{f}$ ). It is saturated by a sulfide inclusion (Figure 2f) or V-W-bearing rutile. In reflected light, coulsonite-I is grey, the internal reflection is not observed (Figure $2 \mathrm{f}$ ). The chemical composition of coulsonite-I is given in (Table 2). It is characterized by uniformly high content of $\mathrm{Cr}_{2} \mathrm{O}_{3}$ (20-30 wt.\%), $\mathrm{ZnO}$ (up to 4.5 wt.\%) and $\mathrm{MnO}$ (2.8 wt.\%) and low content of FeO. The calculation of coulsonite-I formula and distribution of $\mathrm{Fe}^{2+}$ and $\mathrm{Fe}^{3+}$ according to stoichiometry in the spinel group minerals and charge balance indicates that coulsonite-I does not contain $\mathrm{Fe}^{3+}$. That is perfectly demonstrated in a triangle diagram of cation distribution in the structural positions A-B (Figure 3a,b), where coulsonite-I forms a separate group of points.
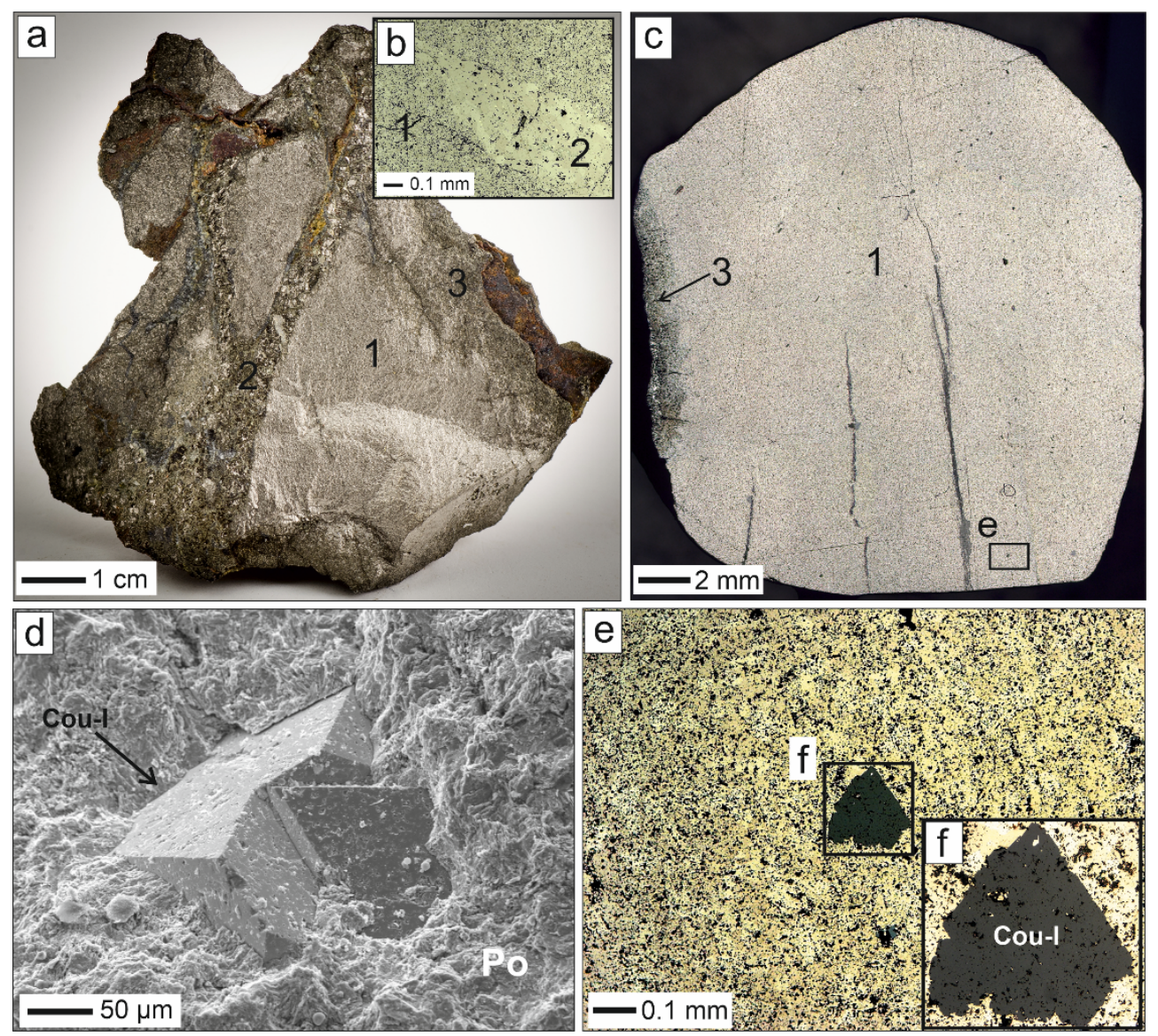

Figure 2. Coulsonite-I (Cou-I) in massive pyrrhotite ores of type I (mPo-I): (a) - sample of mPo-I (1-the main mass of hexagonal and monocline pyrrhotite; 2 -microveins of hexagonal pyrrhotite; 3-oxidation zone); (b,c)-mPo-I in a polished section (reflected light images); (d) - intergrowth of coulsonite crystals in mPo-I (SE image); (e,f)-metacrystal of Cou-I in the main mass of pyrrhotite (reflected light images). The mineral abbreviations hereafter are according to [33], apart from those introduced by the author for rare minerals. SE—-secondary electron. 


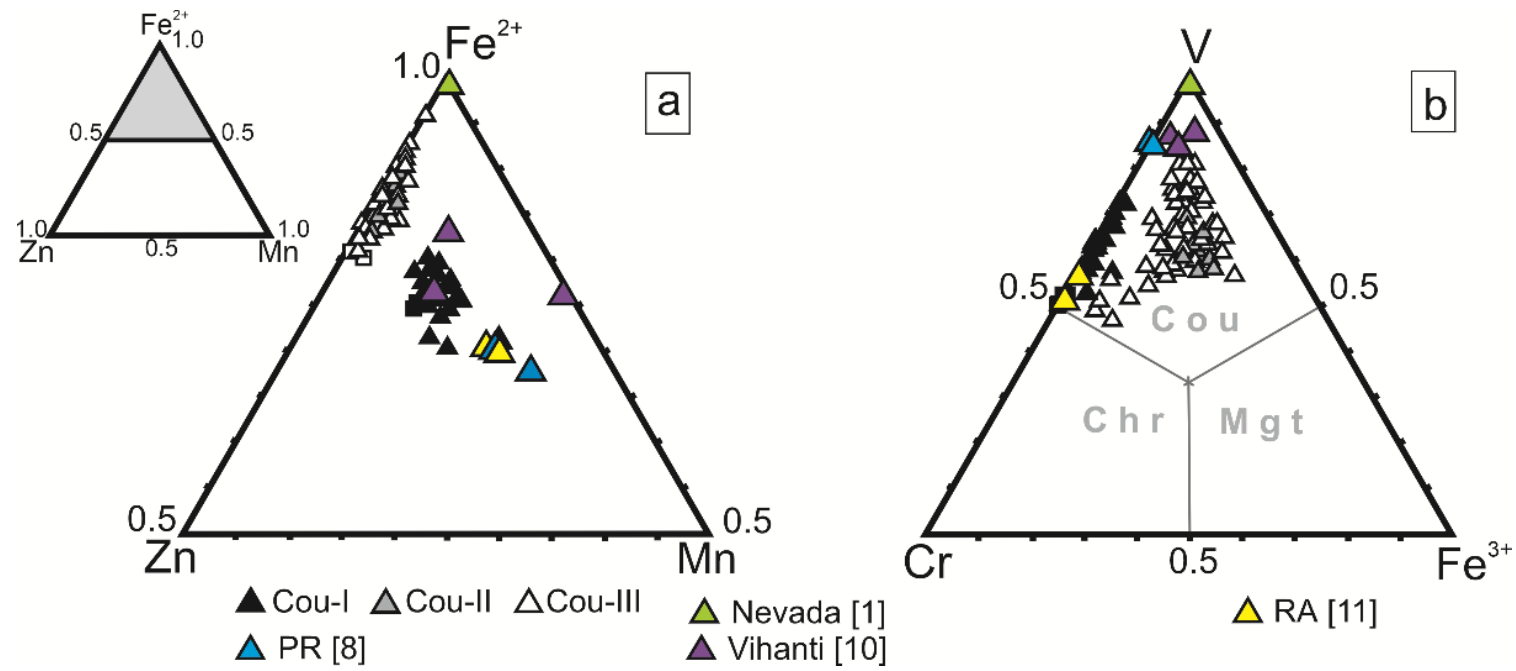

Figure 3. Triangle diagrams of cation distribution in coulsonite from different massive sulfide deposits: (a)—in position $A ;(\mathbf{b})$-in position $B$ (according to the main structural formula $\mathrm{AB}_{2} \mathrm{O}_{4}$ of the spinel group minerals).

Microhardness of coulsonite-I is $743 \mathrm{~kg} / \mathrm{mm}^{2}$ (average of 15 measurements), which exceeds microhardness of coulsonite in the literature $\left(338 \mathrm{~kg} / \mathrm{mm}^{2}\right)$ [8,34]. A coefficient of coulsonite-I reflection (Table 3) significantly differs from coulsonite from the Pyrrhotite Ravine, which is close to standard coulsonite [8].

Table 2. Chemical composition (Wavelength Dispersive Spectrometer (WDS), wt.\%) of coulsonite from the massive sulfide ore of the Kola region.

\begin{tabular}{|c|c|c|c|c|c|c|c|c|c|c|}
\hline Samples & \multicolumn{3}{|c|}{ Coulsonite-I } & \multicolumn{3}{|c|}{ Coulsonite-II } & \multicolumn{3}{|c|}{ Coulsonite-III } & Coulsonite * \\
\hline $\mathrm{SiO}_{2}$ & n.d. & n.d. & 0.01 & n.d. & n.d. & n.d. & 0.05 & n.d. & 0.01 & n.d. \\
\hline $\mathrm{TiO}_{2}$ & 0.29 & 0.44 & 0.22 & 18.77 & 0.53 & 8.77 & 0.54 & n.d. & 0.90 & n.d. \\
\hline $\mathrm{Al}_{2} \mathrm{O}_{3}$ & 0.99 & n.d. & 1.02 & 0.62 & 1.64 & 1.15 & 2.46 & 0.49 & 0.89 & n.d. \\
\hline $\mathrm{FeO}$ & 25.69 & 27.33 & 27.21 & 31.30 & 42.86 & 38.66 & 35.82 & 39.61 & 40.83 & 25.63 \\
\hline $\mathrm{ZnO}$ & 4.48 & 3.32 & 3.79 & 0.72 & 3.11 & 2.12 & 4.12 & 2.04 & 2.32 & 2.74 \\
\hline $\mathrm{MnO}$ & 2.34 & 2.55 & 2.31 & n.d. & 0.18 & 0.10 & 0.09 & n.d. & 0.02 & 5.08 \\
\hline Total & 99.57 & 99.99 & 99.53 & 99.18 & 99.92 & 99.32 & 99.63 & 99.33 & 99.15 & $99.06 * *$ \\
\hline $\mathrm{Al}$ & 0.04 & - & - & 0.03 & 0.07 & - & 0.11 & 0.02 & - & - \\
\hline $\mathrm{Cr}$ & 0.97 & 0.59 & - & 0.20 & 0.35 & - & 0.84 & 0.22 & - & 0.29 \\
\hline V & 0.98 & 1.38 & - & 1.15 & 1.24 & - & 0.86 & 1.54 & - & 1.67 \\
\hline $\mathrm{Fe}^{3+}$ & - & 0.02 & - & 0.13 & 0.32 & - & 0.17 & 0.22 & - & - \\
\hline $\mathrm{Fe}^{2+}$ & 0.84 & 0.86 & - & 0.98 & 0.92 & - & 0.89 & 0.96 & - & 0.81 \\
\hline $\mathrm{Zn}$ & 0.10 & 0.07 & - & 0.02 & 0.08 & - & 0.11 & 0.04 & - & 0.08 \\
\hline Mn & 0.06 & 0.07 & - & - & 0.01 & - & 0.003 & - & - & 0.16 \\
\hline
\end{tabular}

Note. av ()—average content (quantity of analysis); n.d.-element is not detected; * data after [8]; ${ }^{* *}+\mathrm{MgO}-0.08$ wt. $\%$ and $\mathrm{CaO}-0.03$ wt. \%. apfu - atoms per formula units. $\mathrm{Fe}^{2+}$ and $\mathrm{Fe}^{3+}$ calculation based on stoichiometry of the spinel group minerals and charge balance. Dash - apfu $<0.01$ or absent for average content. 
Table 3. Coefficients of reflection of the $\mathrm{Cr}-\mathrm{V}$ spinel group minerals from the Kola region.

\begin{tabular}{cccccc}
\hline $\boldsymbol{\Lambda}, \mathbf{n m}$ & $\mathbf{1}$ & $\mathbf{2}$ & $\mathbf{3}$ & $\mathbf{4}$ & $\mathbf{5}$ \\
\hline 400 & 16.19 & 17.71 & 15.78 & 14.93 & 16.64 \\
420 & 16.12 & 17.24 & 15.79 & 15.01 & 16.44 \\
440 & 16.09 & 16.85 & 15.81 & 15.08 & 16.28 \\
460 & 16.06 & 16.6 & 15.83 & 15.14 & 16.21 \\
480 & 16.04 & 16.39 & 15.85 & 15.2 & 16.18 \\
500 & 16.01 & 16.24 & 15.88 & 15.25 & 16.18 \\
520 & 15.98 & 16.14 & 15.93 & 15.3 & 16.23 \\
540 & 15.95 & 16.07 & 15.98 & 15.34 & 16.3 \\
560 & 15.93 & 15.98 & 16.01 & 15.37 & 16.38 \\
580 & 15.91 & 15.92 & 16.06 & 15.4 & 16.46 \\
600 & 15.88 & 15.86 & 16.12 & 15.42 & 16.54 \\
620 & 15.89 & 15.8 & 16.21 & 15.45 & 16.67 \\
640 & 15.9 & 15.74 & 16.33 & 15.48 & 16.83 \\
660 & 15.94 & 15.74 & 16.45 & 15.49 & 17.03 \\
680 & 16.03 & 15.8 & 16.56 & 15.51 & 17.26 \\
700 & 16.13 & 15.99 & 16.66 & 15.53 & 17.5 \\
\hline
\end{tabular}

Note. 1-chromite in coulsonite-III. 2-coulsonite-I. 3-coulsonite-III. 4-coulsonite-III with the minimum Cr content. 5-coulsonite after [8].

\subsection{Coulsonite-II}

Coulsonite-II was found in relics of quartz-albite veins from massive pyrrhotite ores of type II (Figure 4a,b) and the massive pyrite ore. The relics have a zonal and banded structure where their axial band is composed of albite and two marginal bands built up by quartz. Only the albite axial band hosts a Cr-Sc-V-bearing mineralization (Figure 4c,d).

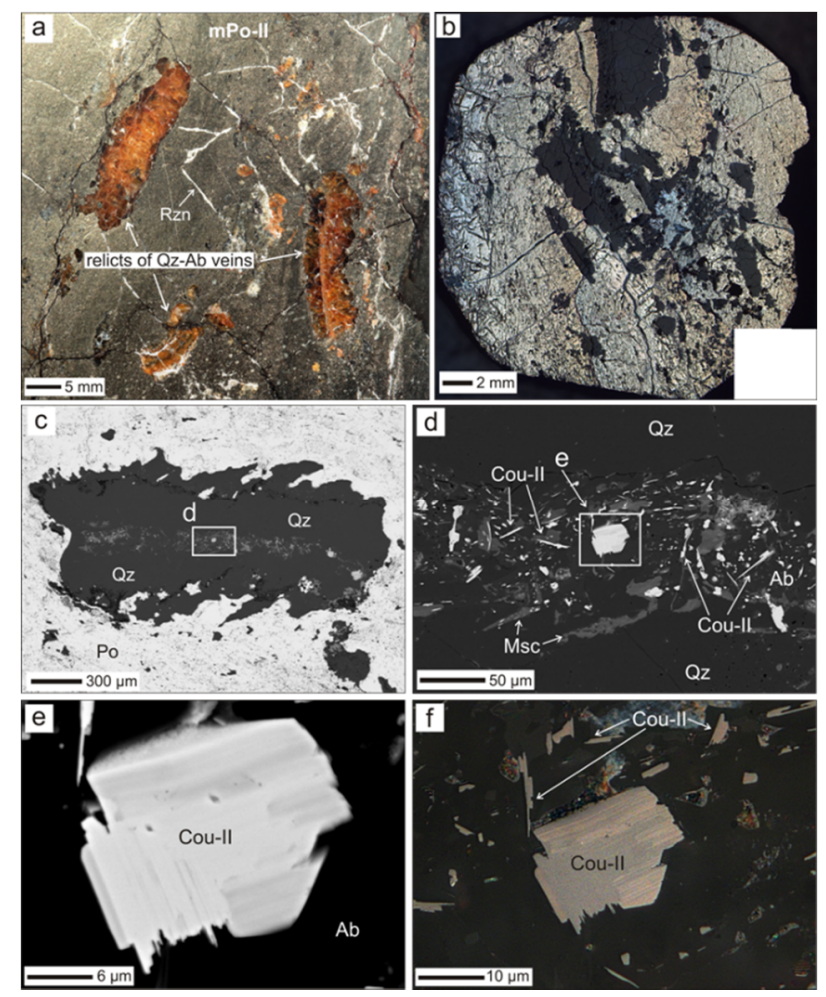

Figure 4. Coulsonite-II (Cou-II) in relics of quartz-albite (Qz-Ab) veins: (a) -relics of Qz-Ab veins in the sample of massive pyrrhotite ores of type II (mPo-II) (Rzn-rozenite); (b-d)—relics of Qz-Ab veins (dark grey) in a polished section of mPo-II (reflected light images); (e,f)-Cou-II in the BSE image (e) and reflected light images (f). Msc-muscovite. BSE-back-scattering electron. 
Coulsonite-II forms thin tabular (needle-like in a section) crystals and crystal clusters (Figure 4e,f), dimensions of which vary from $2 \times 10$ to $10 \times 30 \mu \mathrm{m}$. Crystals of coulsonite-II are usually randomly located in albite, yet, in some cases, some orientation is observed. In association with coulsonite-II roscoelite, V-bearing muscovite, thortveitite, $\mathrm{Sc}-\mathrm{V}$-bearing crichtonite group minerals, rutile, byrudite and tivanite were defined. In reflected light, coulsonite-II is light grey, and the enrichment of crystals in $\mathrm{TiO}_{2}$ has much higher coefficient of reflection and cream tint (Figure 4f).

The chemical composition of coulsonite-II (Table 2) is rather similar to coulsonite-III. This is characterized by a higher content of $\mathrm{FeO}$ and a lower content of $\mathrm{V}_{2} \mathrm{O}_{3}$ and $\mathrm{Cr}_{2} \mathrm{O}_{3}$. A content of $\mathrm{ZnO}$ does not exceed $3 \mathrm{wt} . \%$, while $\mathrm{MnO}$ is under $0.5 \mathrm{wt} . \%$. For some crystals of coulsonite-II, an extremely high $\mathrm{TiO}_{2}$ content was established (up to $18 \mathrm{wt} . \%$ ). These crystals are clearly visible in BSE images (Figure 4e) and reflected polarized light photos (Figure 4f). After [35], a maximum content of $\mathrm{TiO}_{2}$ (3 wt.\%) in coulsonite was described for that from Kalgoorli. Due to its unusual morphology and chemical composition, coulsonite-II is similar to nolanite described in [36]. It is impossible to measure microhardness and precise value of the reflection coefficient due to a small size of coulsonite-II crystals. For the same reason, we have only an EDS analysis of coulsonite-II. For coulsonite-II, the EBSD confirmation method was used (Figure 5). It was based on comparison of data obtained for coulsonite-II and taken from AMCSD [37] CIF data for coulsonite (0015774), nolanite (0000910) in an Oxford Instruments AZtecHKL analysis software where coulsonite was confirmed on 12 bands.
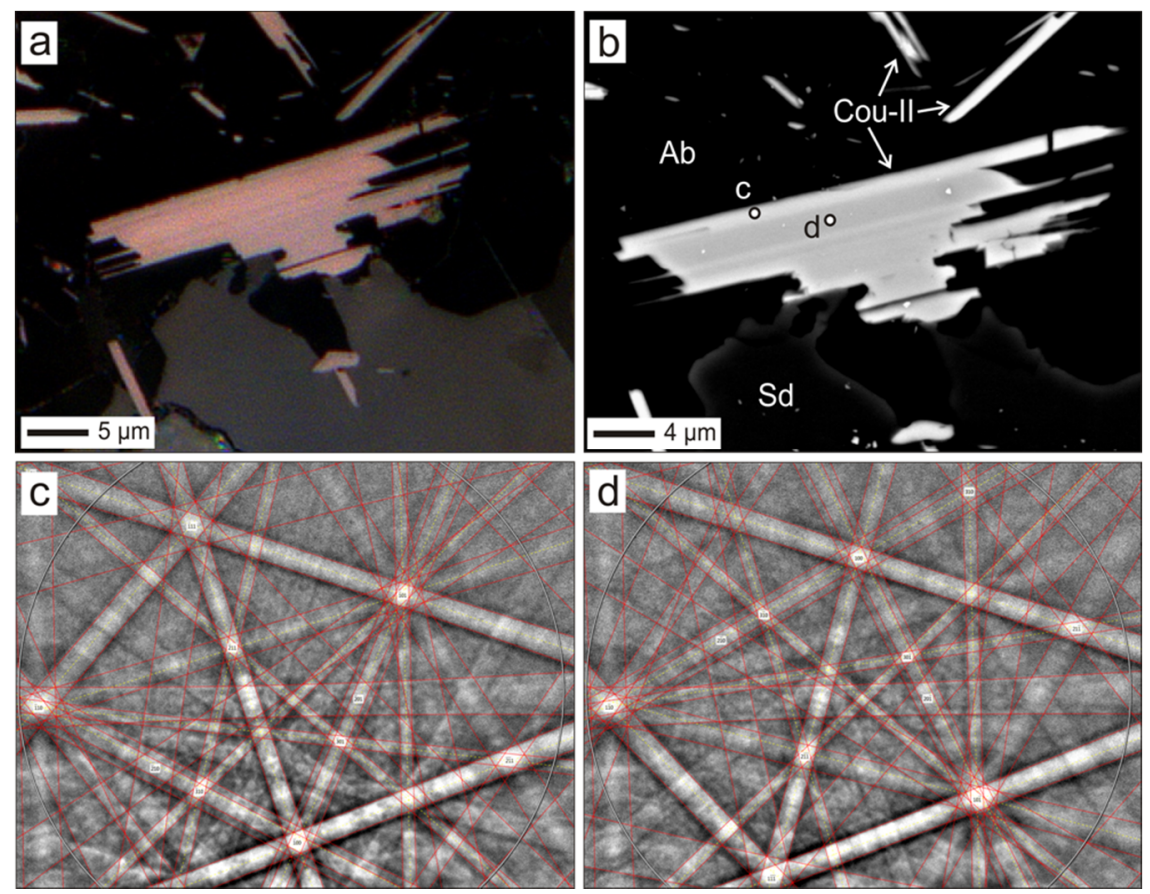

Figure 5. Coulsonite-II (Cou-II) with a different $\mathrm{TiO}_{2}$ content: (a)—reflected light images; (b)—BSE image; (c,d)_EBSD image for Cou-II. Ab—albite.

\subsection{Coulsonite-III}

Coulsonite-III is the most common variety in sulfide ores of the Bragino occurrence. It was found in massive pyrrhotite ores of type II and massive pyrite ores. Massive pyrrhotite ores of type II differ from the type I by a strong cracking, presence of relics of quartz-albite veins, hexagonal pyrrhotite predominance (Figure 6a,b), and more diversified mineral composition [23]. The major minerals of this ore type are pyrrhotite, chalcopyrite, sphalerite, pyrite, and marcasite. Arsenopyrite, molybdenite, galena, cobaltite, altaite, hessite, volynskite, rucklidgeite, kotulskite, gold, etc. were defined as minor and rare minerals. The massive pyrite ore consists of coarse-grained pyrite (Figure 6a) and pyrrhotite, 
chalcopyrite, sphalerite, quartz, albite and siderite in interstitial space. Pyrite contains a lot of inclusions of individual minerals (sulfides, oxides, quartz, etc.) and a mineral association observed only in these pyrite ores [23].
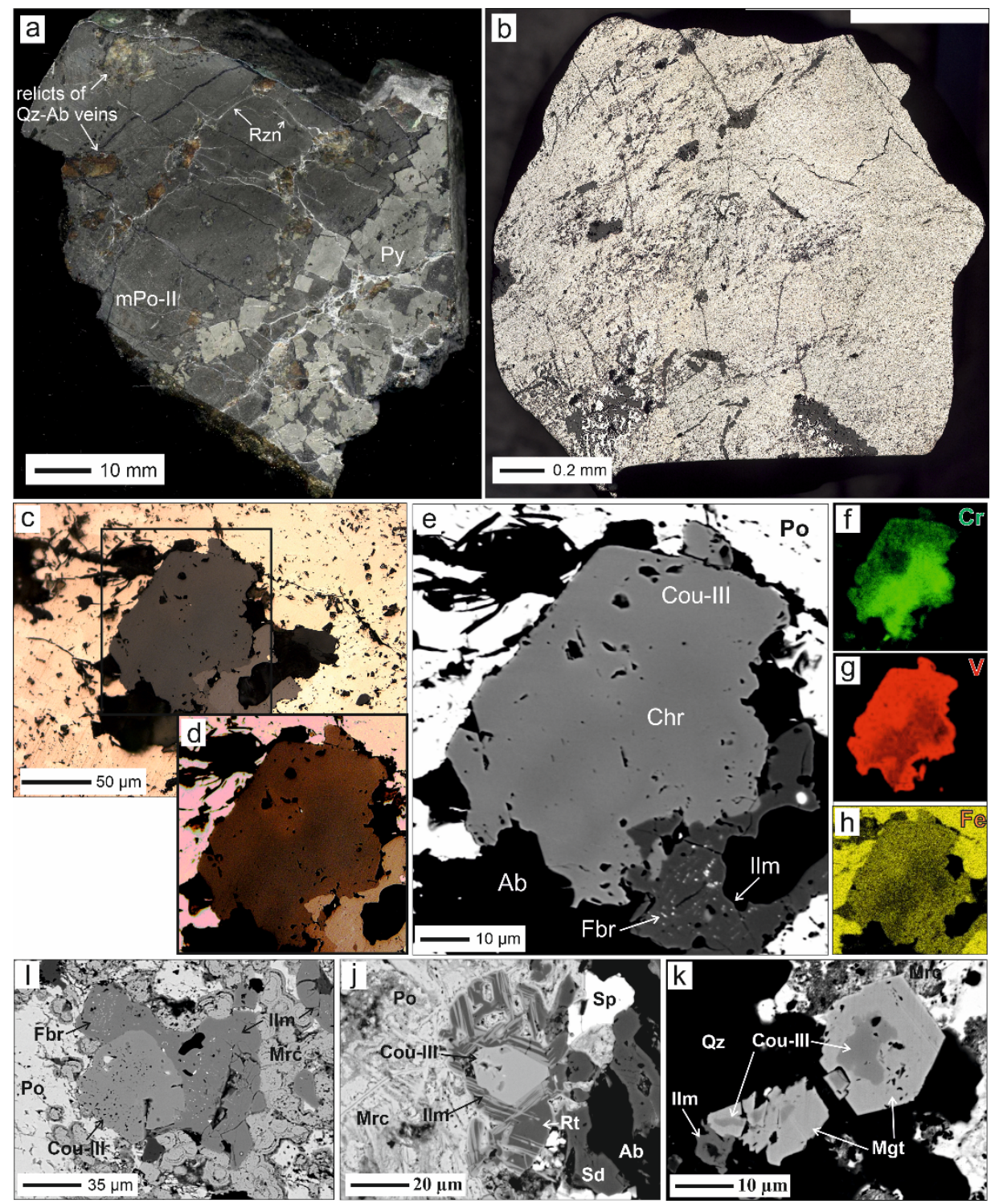

Figure 6. Coulsonite-III (Cou-III) in the massive pyrrhotite ore of type II (mPo-II): (a)—polished sample of mPo-II (Py-pyrite; Rzn—rozenite); (b) - mPo-II in a polished section (reflected light images), (c,d) - coulsonite (brown) with a relic of chromite (Chr, dark grey) in mPo-II; (reflected light images); (e)-BSE image of coulsonite from $(\mathbf{c}, \mathbf{d}) ;(\mathbf{f}-\mathbf{h})$-element mapping of coulsonite from (c,d); (i,j) - coulsonite-III intergrowth with V-bearing ilmenite (Ilm) (i) and rutile(Rt)-ilmenite aggregate (j); (k)—rim of magnetite around coulsonite-III. Ab—albite, Qz-quartz, Mrc-marcasite, Sd—siderite, $\mathrm{Sp}$-sphalerite.

The morphology of coulsonite-III is extremely diverse. It forms individual corroded octahedral crystals up to $150 \mu \mathrm{m}$, crystal clusters, and intergrowths with other minerals. For coulsonite-III, four separate mineral associations are typical: 1-coulsonite-III containing relics of chromite, with an intergrowth with V-bearing ilmenite (up to $3 \mathrm{wt} . \% \mathrm{~V}_{2} \mathrm{O}_{3}$ ) (Figure 6c-i) [9]. Relics of chromite in the central part of coulsonite-III crystals are perfectly distinguished in the reflected light image and element mapping (Figure 6e), however, are not observed in the BSE images because of the proximity of vanadium and chromium atomic mass. It has a lower coefficient of reflection (Table 3), the $\mathrm{V}_{2} \mathrm{O}_{3}$ and 
$\mathrm{Cr}_{2} \mathrm{O}_{3}$ contents are $22 \mathrm{wt} . \%$ and $32 \mathrm{wt} . \%$, respectively. Ilmenite is saturated in a ferberite inclusion (Figure 6e,i). 2-coulsonite-III in an intergrowth with W-V-bearing rutile and ilmenite (and kyzylkumite only in the pyrite ores) (Figure 6j). 3-coulsonite-III surrounded by a V-bearing magnetite rim $\mathrm{V}_{2} \mathrm{O}_{3}$ up to $1.5 \mathrm{wt}$.\% (Figure $6 \mathrm{k}$ ). 4 -coulsonite-III with nolanite in the marginal area or tin inclusion only in the pyrite ores (Figure 7 ).

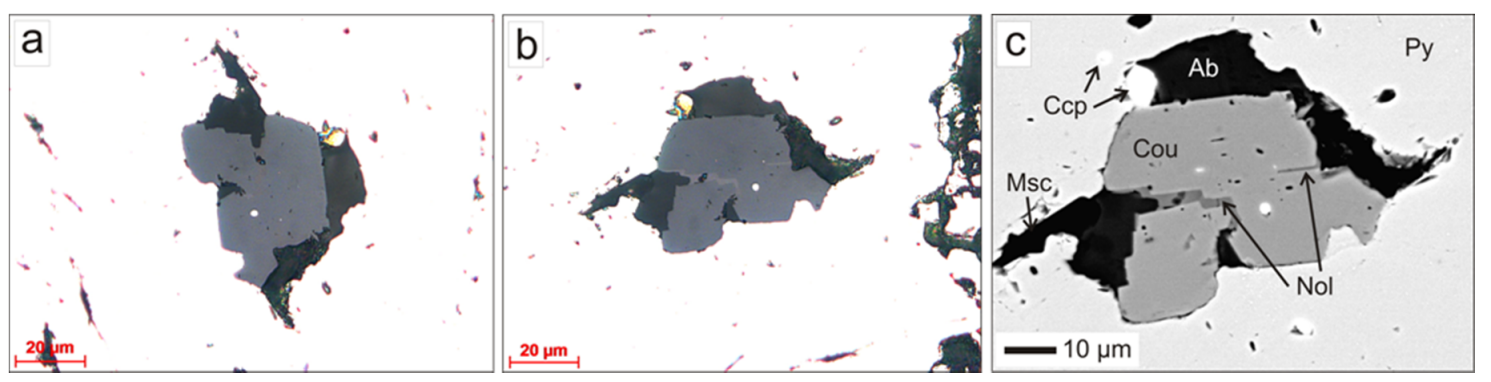

Figure 7. Coulsonite-III (Cou) crystal with nolanite (Nol) in the marginal area from massive pyrite ores: (a)—reflected light images; (b)—the same image rotated 90 ; (c)—BSE images. Ab—albite, Ccp—chalcopyrite, Msc-muscovite, Py—pyrite.

The microhardness of coulsonite-III is $577 \mathrm{~kg} / \mathrm{mm}^{2}$. The reflection coefficient of coulsonite-III is given in Table 3.

\section{Discussion}

\subsection{Genesis of Coulsonite of the Bragino Occurrence}

The vanadium mineralization of the Bragino occurrence was found only in massive sulfide ores and was not established in the host rock. The vanadium mineralization genesis is partially discussed elsewhere [22]. Findings of vanadium oxides or silicates in massive sulfide ores are rather unusual. Formation of vanadium mineralization requires two pre-conditions: (1) primary enrichment of the host rock in vanadium and (2) high degree of metamorphism (up to amphibolite facies). These conditions are met both for the Bragino occurrence and for other objects in which vanadium mineralization was described [9-13,22]. In dispersed state, vanadium is located in sulfide in volcanic-hosted massive sulfide (VHMS) complexes [38]. The source of vanadium can be an organic suspension, which absorbs it from seawater and precipitates with sulfides captured by them [39]. After [40-43], the metamorphism and secondary hydrothermal stage of primary (where pyrite is the main mineral) massive sulfide ores led to the remobilization and redistribution of elements located in sulfides in the dispersed state and to their concentration in newly formed sulfide minerals or in their own mineral phases. The metamorphic recrystallization of sulfides can possibly form vanadium oxides containing coulsonite-I and coulsonite-III.

The findings of V-Sc-bearing minerals in relics of primary hydrothermal veins of the Bragino sulfide ores suggest that these veins were formed at a hydrothermal event that preceded the metamorphic recrystallization of the sulfide ores and that coulsonite-II is of a hydrothermal origin.

\subsection{Chemical Composition of Coulsonite of the Bragino Occurrence}

The chemical composition of coulsonite of the Bragino occurrence has several special features distinguishing it from the one of the Pyrrhotite Valley or Vihanti, which are the nearest similar objects. It is related to the genesis of ores enclosing vanadium mineralization and their metamorphic alteration.

Coulsonite-I and coulsonite-III have the similar genesis but they were established in different types of pyrrhotite ores of the Bragino occurrence, and clearly differ in their chemical composition (Table 2, Figure 3). The chemical composition of coulsonite is different because of the wide isomorphic substitution in both structural positions. 
In tetrahedral A-position, the main cation is $\mathrm{Fe}^{2+}$ (more than $0.8 \mathrm{apfu}$ ) in all coulsonite varieties, $\mathrm{Zn}$ and $\mathrm{Mn}$ admixtures are more substantial in coulsonite-I (Figure 3a). In octahedral B-position, the main cation is $\mathrm{V}^{3+}$ mainly substituted by $\mathrm{Cr}^{3+}$ and $\mathrm{Fe}^{3+}$ (Figure $3 \mathrm{~b}$ ), $\mathrm{Al}$, Ti, Si are present in small amounts. The vanadium content is approximately the same within coulsonite varieties (about $1 \mathrm{apfu}$ ). In B-position of coulsonite-I, $\mathrm{V}^{3+}$ is mainly substituted by $\mathrm{Cr}^{3+}, \mathrm{Fe}^{3+}$ is absent according to formulae calculation. In coulsonite-II and coulsonite-III the inverse dependence between $\mathrm{Cr}^{3+}$ and $\mathrm{Fe}^{3+}$ content is observed. The chemical composition of coulsonite-II is similar to coulsonite-III, yet some crystals of coulsonite-II have the high $\mathrm{TiO}_{2}$ content (up to $18 \mathrm{wt} . \%$ ). Ti probably substitutes $\mathrm{Cr}^{3+}$ and $\mathrm{Fe}^{3+}$ (Table 2).

A massive chromium admixture could be associated with mafic-ultramafic volcanism. The central part of some crystals is enriched in chrome, and can indicate a presence of chromite in primary ores like in the Urals, for example [40] and its subsequent substitution by coulsonite.

After [43], in pyrrhotite ores of massive sulfide deposits embedded in rocks metamorphosed until the amphibolite facies level, there are not only metamorphic alteration of iron sulfides, but significant changes in mineral occurrence forms of zinc, barium, and other elements. These changes in zinc mineralogy were studied in pyrite deposits of the Appalachian and Scandinavian Caledonides, where a substitution of sphalerite by zinc-bearing spinels and silicates was observed [44]. Zinc started accumulating in coulsonite due to metamorphic transformations of sphalerite-bearing ores and redistribution of zinc. Each vanadium spinel has a chrome analogue: chromite $\mathrm{FeCr}_{2} \mathrm{O}_{4}$-coulsonite $\mathrm{FeV}_{2} \mathrm{O}_{4}$, magnesiochromite $\mathrm{MgCr}_{2} \mathrm{O}_{4}$-magnesiocoulsonite $\mathrm{MgV}_{2} \mathrm{O}_{4}$, manganochromite $\mathrm{MnV}_{2} \mathrm{O}_{4}$-vuorelainenite $\mathrm{MnV}_{2} \mathrm{O}_{4}$. Zincochromite $\mathrm{ZnCr}_{2} \mathrm{O}_{4}$ still does not have a vanadium analogue, yet, the ability of zinc to substitute iron in coulsonite can help to discover this mineral in massive sulfide ores rich in sphalerite.

It is noted that the $\mathrm{Cr}$ content in coulsonite has a direct impact on its physical properties. The high content of $\mathrm{Cr}_{2} \mathrm{O}_{3}$ (up to $20 \mathrm{wt} . \%$ and higher) leads to microhardness being doubled, on average. Reflection coefficient increases up to $550 \mathrm{~nm}$ and decreases after (Table 3). In polarized light, coulsonite enriched by chromium looks darker (Figure $6 \mathrm{c}, \mathrm{d}$ ). A difference between the $\mathrm{Cr}$ content in the dark central part and the brown boundary part of the crystal in (Figure 6c,d) is ca. $10 \mathrm{wt} . \%$.

\section{Conclusions}

Findings of vanadium spinels are typical of the Paleoproterozoic high metamorphic VHMS ores like the Vihanty, Outokumpu or Kola region deposits. Three varieties of coulsonite were defined and described in the Bragino massive sulfide ores in the Kola region, Russia based on their chemical composition, some physical properties, and mineral association: coulsonite-I, coulsonite-II, and coulsonite-III. Wide variations in the chemical composition of coulsonite are caused by the isomorphic substitution between $\mathrm{V}, \mathrm{Cr}$ and $\mathrm{Fe}$. Coulsonite-I forms octahedral crystal clusters of up to $500 \mu \mathrm{m}$, and has a uniformly high content of $\mathrm{Cr}_{2} \mathrm{O}_{3}, \mathrm{ZnO}$, and $\mathrm{MnO}$. Coulsonite-II was found in relics of quartz-albite veins in association with other vanadium minerals. It forms a thin tabular shape and is enriched in $\mathrm{TiO}_{2}$. Coulsonite-III is the most common variety in massive sulfide ores of the Bragino occurrence. Coulsonite-III forms octahedral crystals and crystal clusters, intergrowths with V-bearing ilmenite, $\mathrm{W}$-V-bearing rutile, etc. In some crystals of coulsonite-III, relics of chromite are observed. The $\mathrm{Cr}$ admixture mainly has a direct influence on coulsonite physical properties, such as microhardness and reflection coefficient. Increasing the content of $\mathrm{Cr}_{2} \mathrm{O}_{3}$ leads to microhardness being doubled, on average. Three varieties of coulsonite were formed due to metamorphic and hydrothermal alteration of the primary massive sulfide ore, which contains vanadium in a dispersed state in sulfide. In addition, it should be noted that conventional BSE images do not reveal the features of the distribution of $\mathrm{Cr}$ and $\mathrm{V}$ in $\mathrm{Cr}-\mathrm{V}$ spinels, and elemental mapping should be used.

Funding: This research was funded by the Geological Institute of the Kola Science Centre of the RAS in the context of scientific themes 0226-2019-0053. 
Acknowledgments: The author thanks A.V. Voloshin (GI KSC RAS) for consultation, A.V. Bazai (GI KSC RAS) and N.S. Vlasenko, V.V. Shilovskikh from the Resource Center "Geomodel" of the Saint Petersburg State University for helping in mineralogical investigations. The author is grateful to two anonymous reviewers and the Editor for their help on improving this paper.

Conflicts of Interest: The author declares no conflict of interest.

\section{References}

1. Radtke, A.S. Coulsonite, $\mathrm{FeV}_{2} \mathrm{O}_{4}$, a spinel-type mineral from Lovelock, Nevada. Am. Mineral. 1962, 47, 1284-1291.

2. Harris, C.; Hlongwane, W.; Gule, N.; Scheepers, R. Origin of tanzanite and associated gemstone mineralization at Merelani, Tanzania. S. Afr. J. Geol. 2014, 117, 15-30. [CrossRef]

3. Olivier, B. The Geology and petrology of the Merelani tanzanite deposit, NE Tanzania. Ph.D. Thesis, University of Stellenbosch, Stellenbosch, South Africa, 2006; 453p.

4. Reznitsky, L.Z.; Skliarov, E.V.; Ushchapovskaia, Z.F. Natalyite $\mathrm{Na}(\mathrm{V}, \mathrm{Cr}) \mathrm{Si}_{2} \mathrm{O}_{6}$-A new chromium-vanadium pyroxene from Slyudianka. Proc. Russ. Mineral. Soc. 1985, 114, 630-635. (In Russian)

5. Reznitsky, L.Z.; Sklyarov, E.V.; Ushchapovskaya, Z.F. Magnesiocoulsonite $\mathrm{MgV}_{2} \mathrm{O}_{4}$-A new mineral species in the spinel group. Proc. Russ. Mineral. Soc. 1995, 124, 91-98. (In Russian)

6. Reznitsky, L.Z.; Sklyarov, E.V.; Armbruster, T.; Ushchapovskaya, Z.F.; Galuskin, E.V.; Polekhovsky, Y.S.; Barash, I.G. The new mineral oxyvanite $\mathrm{V}_{3} \mathrm{O}_{5}$ and the oxyvanite-berdesinskiite $\mathrm{V}_{2} \mathrm{TiO}_{5}$ isomorphic join in metamorphic rocks of Sludyanka complex (South Baikal region). Proc. Russ. Mineral. Soc. 2009, 138, 70-81. (In Russian)

7. Cametti, G.; Armbruster, T.; Reznitsky, L.Z.; Sklyarov, E.V.; Della Ventura, G. Crystal structure and crystal-chemistry of vanadio-pargasite: A new amphibole from southern Lake Baikal, Siberia, Russia. Eur. J. Mineral. 2018, 30, 981-987. [CrossRef]

8. Karpov, S.M.; Voloshin, A.V.; Savchenko, Y.E.; Selivanova, E.A.; Polekhovsky, Y.S. Coulsonite in the Pyrrhotite Canyon deposit (Kola peninsula): The first find in Russia. Dokl. Earth Sci. 2012, 446, 1064-1066. (In Russian) [CrossRef]

9. Kompanchenko, A.A.; Voloshin, A.V.; Bazai, A.V.; Polekhovsky, Y.S. Evolution of Cr-V mineralization in volcanic massive sulfide ore of Bragino occurences (South Pechenga structure zone, the Kola region) on example of spinel group minerals. Proc. Russ. Miner. Soc. 2017, 5, 44-59. (In Russian)

10. Sergeeva, N.E.; Eremin, N.I.; Dergachev, A.L. Vanadium mineralization in ore of the Vihanti massive sulfide base-metal deposit, Finland. Dokl. Earth Sci. 2011, 436, 210-212. [CrossRef]

11. Höller, W.; Stumpfl, E.F. Cr-V oxides from the Rampura Agucha Pb-Zn-(Ag) deposit, Rajasthan, India. Can. Miner. 1995, 33, 745-752.

12. Zakrzewski, M.A.; Burke, E.A.J.; Lustenhouwer, W.J. Vourelainenite, a new spinel, and associated minerals from the Sätra (Doverstorp) pyrite deposit, central Sweden. Can. Miner. 1982, 20, 281-290.

13. Long, J.V.P.; Vourelainen, Y.; Kuovo, O. Karelianite, a new vanadium mineral. Am. Miner. 1963, 48, 33-41.

14. Rouhunkoski, P. On the geology and geochemistry of the Vihanti zinc ore deposit, Finland. Bull. Comm. Geol. Finl. 1968, 236, 121.

15. Rauhamäki, E.; Mäkelä, T.; Isomäki, O.P. Geology of the Vihanti mine. In Precambrian Ores of Finland. Guide to Excursions $078 \mathrm{~A}+\mathrm{C}$, Part 2 (Finland), Proceedings of the 26th International Geological Congress, Paris, France 7 July 1980; Häkli, T.A., Ed.; Geological Survey of Finland: Espoo, Finland, 1980; pp. 14-24.

16. Gandhi, S.M.; Paliwal, H.V.; Bhatnagar, S.N. Geology and ore reserve estimates of Rampura Agucha lead zinc deposit, Bhilwara District. J. Geol. Soc. India 1984, 25, 689-705.

17. Deb, M.; Thorpe, R.L.; Cumming, G.L.; Wagner, P.A. Age, source and stratigraphic implications of Pb isotope data for conformable, sediment-hosted, base metal deposits in the Proterozoic Aravalli-Delhi orogenic belt, northwestern India. Precambrian Res. 1989, 43, 1-22. [CrossRef]

18. Deb, M. Lithogeochemistry of rocks around Rampura Agucha massive zinc sulfide ore-body, NWIndia-implications for the evolution of a Proterozoic "Aulakogen". In Metallogeny Related to Tectonics of the Proterozoic Mobile Belts; Sarkar, S.C., Ed.; Balkhema: Rotterdam, the Netherlands, 1992; pp. 1-35.

19. Höller, W.; Gandhi, S.M. Origin of tourmaline and oxide minerals from the metamorphosed Rampura Agucha Zn-Pb-(Ag) deposit, Rajasthan, India. Miner. Petrol. 1997, 60, 99-110. [CrossRef] 
20. Allen, R.L.; Lunström, I.; Ripa, M.; Simeonov, A.; Christofferson, H. Facies analysis of a 1.9 Ga, contintental margin, back-arc, felsic caldera province with diverse $\mathrm{Zn}-\mathrm{Pb}-\mathrm{Ag}-(\mathrm{Cu}-\mathrm{Au})$ sulfide and Feoxide deposits, Bergslagen region, Sweden. Econ. Geol. 1996, 91, 979-1008. [CrossRef]

21. Peltola, E. Origin of Precambrian Copper Sulfides of the Outokumpu Disctrict, Finland. Econ. Geol. 1978, 73, 461-477. [CrossRef]

22. Kompanchenko, A.A.; Voloshin, A.V.; Balagansky, V.V. Vanadium Mineralization in the Kola Region, Fennoscandian Shield. Minerals 2018, 8, 474. [CrossRef]

23. Kompanchenko, A.A.; Voloshin, A.V.; Bazai, A.V. Mineral composition of paleoproterozoic metamorphosed massive sulfide ore of the Kola region on example of Bragino occurrence in South Pechenga. Proc. Russ. Miner. Soc. 2019, 5, 74-88. (In Russian) [CrossRef]

24. Melezhik, V.A.; Sturt, B.A. General geology and evolutionary history of the early Proterozoic Polmak-Pasvik-Pechenga-Imandra/Varzuga-Ust'Ponoy Greenstone Belt in the north-eastern Baltic Shield. Earth Sci. Rev. 1994, 36, 205-241. [CrossRef]

25. Glebovitsky, V.A. (Ed.) Early Precambrian of the Baltic Shield; Nauka: Saint-Petersburg, Russia, $2005 ;$ p. 711. ISBN 5-02-024950-5. (In Russian)

26. Melezhik, V.A.; Prave, A.R.; Hanski, E.J.; Fallick, A.E.; Lepland, A.; Kump, L.R.; Srauss, H. (Eds.) The Palaeoproterozoic of Fennoscandia as Context for the Fennoscandian Arctic Russia-Drilling Early Earth Project. In Reading the Archive of Earth's Oxygenation; Springer: Heidelberg, Germany, 2013; p. 490.

27. Mints, M.V.; Dokukina, K.A.; Konilov, A.N.; Philippova, I.B.; Zlobin, V.L.; Babayants, P.S.; Belousova, E.A.; Blokh, V.I.; Bogina, M.M.; Bush, D.A.; et al. East European Craton: Early Precambrian History and 3D Models of Deep Crustal Structure; Geological Society of America Special Paper 510; Geological Society of America: Boulder, CO, USA, 2015; p. 433.

28. Skuf'in, P.K.; Theart, H.F.J. Geochemical and tectono-magmatic evolution of the volcano-sedimentary rocks of Pechenga and other greenstone fragments within the Kola Greenstone Belt, Russia. Precambrian Res. 2005, 141, 1-48. [CrossRef]

29. Skuf'in, P.K.; Elizarov, D.V.; Zhavkov, V.A. Geological and geochemical pecularities of volcanics of the the South Pechenga structural zone. Proc. Murm. State Technol. Univ. 2009, 12, 416-435. (In Russian)

30. Pouret, O.; Dia, A. Vanadium. In Encyclopedia of Geochemistry; White, W.M., Ed.; Springer: Cham, Switzerland, 2016.

31. Balashov, Y.A. Paleoproterozoic geochronology of the Pechenga-Varzuga structure, Kola Peninsula. Petrology 1996, 4, 3-25. (In Russian)

32. Akhmedov, A.M.; Voronyaeva, L.V.; Pavlov, V.A.; Krupenik, V.A.; Kuznetsov, V.A.; Sveshnikova, K.Y. The gold content of the South Pechenga structural zone (the Kola Peninsula): Types of manifestations and prospects for identifying industrial gold contents. Reg. Geol. Metallog. 2004, 20, 143-165. (In Russian)

33. Whitney, D.L.; Evans, B.W. Abbreviations for names of rock-forming minerals. Am. Miner. 2010, 95, $185-187$. [CrossRef]

34. Anthony, J.W.; Bideaux, R.A.; Bladh, K.W.; Nichols, M.C. (Eds.) Handbook of Mineralogy; Mineralogical Society of America: Chantilly, VA, USA, 2001.

35. Spiridonov, E.M. Titanium coulsonite from Kalgoorlie deposit. Dokl. AS USSR 1979, 245, 447-449. (In Russian)

36. Gatehouse, B.M.; Grey, I.E.; Nickel, E.H. The crystal chemistry of nolanite, $(\mathrm{V}, \mathrm{Fe}, \mathrm{Ti}, \mathrm{Al})_{10} \mathrm{O}_{14}(\mathrm{OH})_{2}$, from Kalgoorlie, Western Australia. Am. Miner. 1983, 68, 833-839.

37. Downs, R.T.; Hall-Wallace, M. The American Mineralogist Crystal Structure Database. Am. Miner. 2003, 88, 247-250.

38. Maslennikov, V.V.; Ayupova, N.R.; Maslennikova, S.P.; Tret'yakov, G.A.; Melekestzeva, I.Y. Toxic Elements in Massive Sulfide Systems; Institute of Mineralogy, the Ural Branch of Russian Academy of Sciences: Miass, Russia, 2014; p. 340. ISBN 978-5-7691-2411-2. (In Russian)

39. Butler, I.B.; Nesbitt, R.W. Trace element distribution in the chalcopyrite wall of a black smoker chimney: Insight from laser ablation inductively coupled plasma mass spectrometry (LA-ICP-MS). Earth Planet. Sci. Lett. 1999, 167, 335-345. [CrossRef]

40. Zaykov, V.V.; Maslennikov, V.V.; Zaykova, E.V.; Herrington, R. Ore-Formation and Ore-Facies Analyses of Massive Sulphide Deposits of the Ural Paleoocean; Institute of Mineralogy, the Ural Branch of Russian Academy of Sciences: Miass, Russia, 2001; p. 315. (In Russian) 
41. Vikentiev, I.V. Precious metal and telluride mineralogy of large volcanic-hosted massive sulfide deposits in the Ural. Miner. Petrol. 2006, 87, 305-326. [CrossRef]

42. Vikent'ev, I.V.; Yudovskaya, M.A.; Moloshag, V.P. Speciation of noble metals and conditions of their concentration in massive sulfide ores of the Urals. Geol. Ore Depos. 2006, 48, 77-107. [CrossRef]

43. Moloshag, V.P.; Grabezhev, A.I.; Vikent'ev, I.V.; Gulyaeva, T.Y. Ore formation facies of massive sulphide ore deposits and copper-gold-porphyry deposits of Urals. Litosfera 2004, 2, 30-51. (In Russian)

44. Spry, P.G.; Scott, S.D. Zincian spinel and staurolite in the Appalachians and Scandinavian caledonides. Can. Miner. 1986, 24, 147-163.

(C) 2020 by the author. Licensee MDPI, Basel, Switzerland. This article is an open access article distributed under the terms and conditions of the Creative Commons Attribution (CC BY) license (http://creativecommons.org/licenses/by/4.0/). 